\title{
NECESSITY FOR SOCIAL INSURANCE
}

\author{
By John Graham Brooks, \\ Cambridge, Mass.
}

I have never been, in all these years, to a public meeting which has given me so much hope that some real constructive good may come out of it as this recent gathering of the Academy. Mr. Hammond called our American Employers' Liability law by its proper name, "iniquitous." And we all seem to be agreed about it. In the hope of getting a little more leverage, and even not being ashamed to make a kind of moral appeal, I have set down notes on a fairly long experience. It is pretty nearly twenty-two years since I was asked by Carroll D. Wright to go to Europe to study this question. It was hard work for two years, with much knocking about Europe, and since then I have done my best, at least, to keep track of the insurance discussion. Soon after that we had a public meeting in Washington on this same subject, but it was then like talking to the stone-deaf ; and now, to come into this new atmosphere shows that the change has come-a change that makes elementary justice a possibility.

I want to tell you the first thing that startled me when I tried to study this question twenty-two years ago in Germany. It is commonplace to us now, but it was not then. It was of a man working in certain dangerous trades in Germany, where his chances of being crippled or killed were fifteen times as great as those of a man working in certain factories or in a sugar refinery, and both got practically the same wage. Society ignorantly permitted an injustice like that. What should we, as parents, think of ourselves for allowing a son to choose freely in those two situations, to say: "You have to earn your own living; but at one trade you run fifteen times the chance of being crippled and get no more pay." You would call a parent that did that inhuman; but that is exactly what society has long been doing in this country. After I came back to America there came into my experience the case of a young man with a family. He crawled under a trolley car every day, as he had to, to examine the car. One day the conductor started it, and left 
the man's leg, the lower part of it, pulp. It had to be amputated twice, followed by extreme suffering, and then the case was held up by litigation nearly seven years. But for years of outside effort, he never would have got a cent, because we were playing this perfectly vicious game of "assumption of risk" and "contributory negligence," under the complicated conditions of modern industry. I saw most of his property paid out, the look of pain grow on the face of his wife. In the end, by a sort of private appeal, that great corporation, which I am not blaming, gave him scarcely enough money to pay the doctor's bills. I began at that time to make collections of every authoritative statement of accident that I could get. They run into thousands. If we multiply them many times yearly, we get some notion of the vast tragedy that is made possible by legal imperfections. We are here practically agreed that these are to be cleaned out, all that "contributory negligence," the "fellow servant doctrine," the "assumption of risk"-all has to be cleaned out, like poison from the system.

I once heard of an Englishman who was asked to give money to go to India to some mission where he had been. He gave a shilling, and took out a gold sovereign in the other hand. "What do you keep these apart for?" he was asked. "That shilling," he replied, "is to go to the heathen, and this sovereign is to pay the bills for getting it there." A great business has reported that under our present laws one dollar in four gets to the injured. Are we to tolerate a waste like that? The fact, and we have got to understand it clearly, is that every cent of this expense has got to be borne, probably first by an insured group of employers, and then go straight where it belongs, into the price of the product. The essence of the German system, in my opinion, we have got to take, though we shall have to adapt it to our conditions. We shall try many voluntary schemes and, except for those who are very strong and least need insurance, we shall find that voluntary schemes do not suffice; and, if I had time I could show you in several countries any amount of attempts at voluntary schemes, that have been a history of failure. In my opinion we have got to be prepared for a very large extension of compulsion, even for the sake of employers, but chiefly for the mass of weaker workers. I have a letter in my hand that I cannot read, because it is so long, from one who knows more about the subject we are talking about than any other living man. The gist of 
that communication is this: "Why do not your universities get competent students to take a record from nine or ten different countries and classify the experience for your own needs? Get this done by the ablest men in your universities, so that when the question comes up in different states, you have facts about every single phase of this legislation? Here we have a vast experience boiled down, country by country, so that all can look at it. I am not asking you to accept our system, but I am asking that you will look at the work of more than twenty years, in eight or nine different countries, where every variety of insurance has been tried." This suggestion is too important to forget.

In concluding, Dr. Talcott Williams rather took my breath away this morning. I have been criticised over and over again for saying that the battles of the Civil War were hardly more deadly than the devastation which we create by carelessness and ignorance in the United States. I have often said that more than half a million were killed or injured every year in our industries, and Mr. Williams said, as I understood him, a million.

The justification which a layman feels in using strong language about this inhumanity of our present accident laws is, that wherever the facts have had thorough discussion, both lawyers and politicians of highest eminence agree in condemning conditions like those now existing in the United States. It was of these that Sir Frederick Pollock said, "I think the doctrine of the American and English courts is bad law as well as bad policy." Of these same conditions (the English act of I880) Mr. Asquith used the words, "A scandal and a reproach to the legislature, an elaborate series of traps and pitfalls for the unwary litigant, and producing litigation which, in proportion to its difficulty and cost, is absolutely barren of result." Lord Salisbury and Mr. Chamberlain both used language scarcely less severe. When the discussion began in the House of Commons, twenty years ago, scores of able men hotly defended these laws. It is now said that no first-rate man in the house will even attempt a defence. At the international congresses for the discussion of accident insurance, the part which "common employment" has paid in our legislature has invariably elicited surprise and disapproval.

Ten years ago a doctor said to me in Berlin, "Before you come over here, I shall be able to show you that we are saving human life enough, in actual days and months, enough of health and energy, 
to pay all these stupendous millions that it costs." I said, "I do not believe it." Two years ago I went to his house in Berlin. He said, "I know what you are going to ask me, and I think I can prove it to you." A German member of Parliament, who has just left this country, confirmed this opinion. He said, "It is true that this pension legislation really carried out systematically, with the help of German science, has saved enough human life and health, measured in dollars, to pay the whole stupendous bill." I know no more remarkable or hopeful sociological fact than that. May it lead us, not in detail, but in general spirit to the same large measure of justice. 